\author{
MaPan : Jurnal Matematika dan Pembelajaran \\ p-ISSN: 2354-6883 ; e-ISSN: 2581-172X \\ Volume 9, No 1, June 2021 (59-84) \\ DOI: https://doi.org/10.24252/mapan.2021v9n1a5
}

\title{
MATHEMATICS CREATIVE THINKING SKILLS INSTRUMENT TO SOLVE CUBE AND RECTANGULAR PRISM VOLUME PROBLEMS FOR ELEMENTARY SCHOOL STUDENTS
}

\author{
Aan Yuliyanto'), Turmudi'2), Ernawulan Syaodih ${ }^{3)}$, Arie Dharmawan ${ }^{4)}$, \\ Cahya Karisma Pertiwi5), Idat Muqodas6), Dadan Rusdiana Saputra7) \\ 1,2,3Primary Education Study Program, School of Postgraduate Studies, Universitas Pendidikan \\ Indonesia \\ 4SDN Klender 06 \\ ${ }^{5}$ Elementary Teacher Education Study Program, Universitas Pendidikan Indonesia \\ ${ }^{6}$ Department of Early Childhood Education, Universitas Pendidikan Indonesia \\ 7SDN Benda 1 \\ 1,2,3Jl. Setiabudhi No. 229 Bandung, Indonesia \\ 4Jl. Pertanian Timur, Klender, Jakarta Timur, Indonesia \\ 5,6Jl. Veteran No. 08 Purwakarta, Indonesia \\ 7Jl. Balai Desa Benda, Karangampel, Indramayu, Indonesia \\ Email: aanyuliyanto@upi.edu1), turmudi@up.edu²), ernawulansy@upi.edu³), \\ ariedharmawan007@gmail.com), cahyakarisma@upi.edu5), idatmuqodas@upi.edu' ${ }^{6}$, \\ saputradadan690@gmail.com 7 )
}

Received February 11, 2021; Revised June 01, 2021; Accepted June 02, 2021

\begin{abstract}
:
Mathematical creative thinking skills can help students solve mathematical problems with diverse, unique, and detailed solutions and strategies. This study aims to produce an instrument capable of obtaining information about students' mathematical creative thinking skills to solve the cube and rectangular prism volume problems for elementary school students. Research and development are applied in this research. The population of this research was sixth-grade elementary school students in Jakarta and West Java. The participants were 33 students in East Jakarta and 15 students in Purwakarta. The sample is based on purposive sampling. The instrument developed was an essay test question. The item validity test shows that the three items are considered accurate for measuring mathematical creative thinking skills correctly. The instrument is considered consistent for measuring mathematical creative thinking skills and can measure mathematical creative thinking skills on similar subjects at different times and places. The difficulty level of the three items is moderate, so that belonging is not too difficult or easy. The discrimination power of the questions is very good to discriminate the skills of students who are classified as high and low. Thus, the mathematical creative thinking skills instrument can be used to understand the mathematical creative thinking skills of sixth-grade and can also be used to measure the mathematical creative thinking skills of fifth-grade elementary school students on the same material for further research.
\end{abstract}

Keywords: Mathematics Creative Thinking Skills, Instrument, Cube and Rectangular Prism

Copyright ( 2021, MaPan: Jurnal Matematika dan Pembelajaran 
Aan Yuliyanto1), Turmudi2), Ernawulan Syaodih3), Arie Dharmawan ${ }^{4)}$, Cahya Karisma Pertiwi'5), Idat Muqodas6), Dadan Rusdiana Saputra7)

\title{
INSTRUMEN KETERAMPILAN BERPIKIR KREATIF MATEMATIS UNTUK MEMECAHKAN MASALAH VOLUME KUBUS DAN BALOK SISWA SEKOLAH DASAR
}

\begin{abstract}
Abstrak:
Keterampilan berpikir kreatif matematis dapat membantu siswa memecahkan masalah matematika dengan solusi dan strategi yang beragam, unik, dan lengkap. Tujuan riset ini adalah untuk memproduksi instrumen yang mampu mendapatkan informasi tentang keterampilan berpikir kreatif matematis siswa. Research and Development diterapkan dalam riset ini. Populasi penelitian ini adalah siswa kelas VI SD di Jakarta dan Jawa Barat. Partisipan sebanyak 33 siswa di Jakarta Timur dan 15 siswa di Purwakarta. Pemilihan sampel berdasarkan teknik purposive sampling. Instrumen yang dikembangkan adalah soal tes esai. Pengujian validitas item menunjukkan ketiga item dianggap akurat sehingga dapat mengukur keterampilan berpikir kreatif matematis dengan benar. Instrumen dianggap konsisten untuk mengukur keterampilan berpikir kreatif matematis dan dapat digunakan untuk mengukur keterampilan berpikir kreatif matematis pada subjek sejenis di waktu dan tempat yang berbeda. Tingkat kesukaran ketiga item tergolong sedang, sehingga tergolong tidak terlalu sukar atau mudah. Daya beda soal tergolong sangat baik, sehingga dapat membedakan keterampilan siswa yang tergolong tinggi dan rendah. Dengan demikian, instrumen keterampilan berpikir kreatif matematis dapat digunakan untuk memahami keterampilan berpikir kreatif matematis siswa kelas enam dan juga dapat digunakan untuk mengukur keterampilan berpikir kreatif matematis siswa kelas lima SD pada materi yang sama untuk penelitian selanjutnya.
\end{abstract}

Kata Kunci: Keterampilan Berpikir Kreatif Matematis, Instrumen, Kubus dan Balok

How to Cite: Yuliyanto, A., Turmudi, T., Syaodih, E., Dharmawan, A., Pertiwi, C. K., Muqodas, I., \& Saputra, D. R. (2021). Mathematics Creative Thinking Skills Instrument to Solve Cube and Rectangular Prism Volume Problems for Elementary School Students. MaPan: Jurnal Matematika dan Pembelajaran, 9(1), 5984. https://doi.org/10.24252/mapan.2021v9n1a5.

\section{INTRODUCTION}

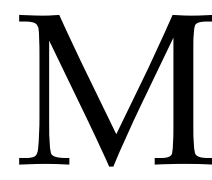

athematical creative thinking skills are one of the skills that students in the 21st century must have and are classified as skills that require deep thinking. This refers to mathematical creative thinking skills included in High-Order Thinking Skills (HOTS) (Pitrianti, 2017). Creative thinking skills are needed to face globalization by increasing students' skills to a higher level in taking the initiative to overcome global problems, especially in the development of science (Al-Mahasneh, 2018). Creative thinking skills are needed when someone is faced with limitations or obstacles and must find 
alternative solutions to problems faced in life in the 21st century (Rizki, 2018; Rosana \& Ekohariadi, 2020; Setiawan, Malik, Suhandi, \& Permanasari, 2018). Thus, creative thinking skills require deep thinking as a part of HOTS. The study says HOTS requires a higher thinking process than just restating the accessed facts (Kusumastuti, Fauziati, \& Marmanto, 2019). Teachers must familiarize students with HOTS questions to find out students' mathematical creative thinking skills. If this is not what the teacher does, knowing mathematical creative thinking skills will not be observed, trained and students will find it difficult and anxious because they are not practiced to it. Research proves students are worried about being asked to do higher-order thinking problems (Rahayu \& Ulya, 2017).

Mathematical creative thinking skills are suggested to be taught since students are still in elementary school so that they are accustomed to thinking creatively so that they can solve all aspects of problems (Arifuddin, 2019). Students who have excellent mathematical creative thinking skills are easier to receive lessons (Rambe, Sinaga, \& Yusnadi, 2018). Mathematical creative thinking skills will encourage students to increase their capacity to solve problems (Sener, Turk, \& Tas, 2015). Students who can think mathematically creatively will be able to have ideas to solve problems systematically, critically, and communicate effectively (McGuinness, 1999). Thus, the capacity to think mathematically creatively is considered to help students solve mathematical problems that are, of course, very much needed by elementary students in everyday life.

Reviewing the results of the 2018 PISA Indonesia ranking study, there was a decrease compared to 2015. The study compared the math problemsolving skills, reading, and science performance of several children (Tohir, 2019). It is necessary to understand that the standard in measuring PISA is based on the HOTS-based learning level (Fitriyah, 2020). Meanwhile, mathematical creative thinking skills have been understood as part of the HOTS level (Ariyana, Pudjiastuti, Bestary, \& Zamromi, 2018). Thus, it is important to teach and train mathematical creative thinking skills from an early age so that students can solve problems, read, and perform well in science. Also, HOTS questions have now been applied to the national examination as an implementation of the 2013 curriculum, which requires students to have HOTS (Oktiningrum \& Wardhani, 2019).

Education is currently is required can develop 21st-century competencies and HOTS. Reviewing the goals of National Education which functions to 
Aan Yuliyanto1), Turmudi2), Ernawulan Syaodih3), Arie Dharmawan ${ }^{4)}$, Cahya Karisma Pertiwi'5), Idat Muqodas6), Dadan Rusdiana Saputra7)

develop abilities and shape the character and civilization of a nation with dignity to educate the nation's life, develop the potential of students to believe and fear God Almighty, knowledgeable, competent, creative, democratic, and responsible (Kemendikbud, 2003). This goal that students must have good mathematical creative thinking skills.

Furthermore, this study will reveal students' mathematical creative thinking skills in mathematics learning in elementary schools. Mathematics learning goals include: Understand mathematical concepts, explain the relationship of concepts and apply concepts of algorithms, are flexible, accurate, efficient, and precise in problem-solving; Using pattern and trait reasoning, performing mathematical manipulations and making generalizations, compiling evidence, or explaining mathematical ideas and statements. Solving problems includes the capability to understand problems, design mathematical models, solve models and interpret solutions; Communicate ideas with symbols, tables, diagrams, or the like to clarify the problem; Having an attitude of appreciating the usefulness of mathematics, namely curiosity, attention, and interest in learning mathematics, as well as being resilient and confident in solving problems (National Council of Teachers of Mathematics, 2000; National Research Council, 2001). Based on these goals, the capacity to think mathematically creatively in solving problems is needed to achieve these goals.

The capacity to think creatively in mathematics is the capacity to provide various answers to a problem, see the problem not only from one point of view, record problems in detail, reveal solutions in different ways than ever before, and explore various answers (Rosyanti, Rohaendi, Zanthy, \& Sylviana, 2019). The study says that elementary students' creative thinking processes in solving mathematical problems are realized by generating ideas to identify known information, using different approaches to planning problem solving, and producing creative products that meet aspects of flexibility (Ishabu, Budayasa, \& Siswono, 2019). Mathematical creative thinking skills as an orientation to mathematical instruction, including discovery and problem-solving tasks (Moma, 2016). The description of mathematical creative thinking skills shows that the capacity to think creative mathematically is the skill of students to find solutions to various problems in terms of answers, strategies, novelty, and describes in detail through logical processes and previously acquired knowledge.

The study reveals four criteria for mathematical creative thinking skills, namely fluency, flexibility, originality, and elaboration. Fluency is the capacity 
to generate many different ideas produced in a given time easily. Flexibility is the number of various strategies that go through during the exploration of ideas. Originality is the uniqueness of an idea in extraordinarily solving problems. Elaboration refers to the detailed and in-depth analysis of related ideas (Evans, 1994; Firdaus, As'ari, \& Qohar, 2018; Wang, Wu, \& Horng, 1999; Yani \& Oikawa, 2019). Mathematical creative thinking skills involve the capability to find novelty. It involves flexibility, originality, fluency, elaboration, brainstorming, modification, delusional, associative thinking, attribute lists, and metaphorical thinking. The indicator used to measure the capacity to think creative mathematically in this study is fluency which is the capacity to produce more than one answer in solving mathematical problems, flexibility which is the capacity to produce answers that vary in solving mathematical problems, originality which is the capacity to produce unique answers in solving problems mathematically, the last is elaboration, namely the capacity to develop detailed answers in solving mathematical problems.

To comprehensively understand students' mathematical creative thinking skills, there must be a measuring instrument in the form of an instrument that can measure mathematical creative thinking skills appropriately and be adapted by other teachers. So that mathematical creative thinking skills can be developed by teachers and researchers.

Research related to developing mathematical creative thinking skills instrument has been carried out by several previous researchers who developed it on elementary, junior high, and high school students. In junior high school students, the mathematical creative thinking skills instrument has validity and reliability classifications, good discriminating power, and easy to moderate difficulty levels, instrument development is only carried out on 24 junior high school students who have received the previous material (Moma, 2016). Furthermore, the development of the mathematical creative thinking skills instrument of fourth-grade elementary school students on the topic of flat shapes has low to high validity, very high reliability, the proportion of difficult levels of difficulty dominates on 8 items, and only 3 items are classified as moderate, and only 1 out of 8 item which has a good level of difficulty (Astuti, Waluya, \& Asikin, 2020). The development of mathematical creative thinking skills instrument in junior high school students after being validated logically by experts and improvements are considered to be tested, then the results of the empirical validity test show that the validity of the item is valid and the reliability is moderate (Silvia, Risnita, \& Syaiful, 2015), In this research, the 
Aan Yuliyanto1), Turmudi2), Ernawulan Syaodih3), Arie Dharmawan ${ }^{4)}$, Cahya Karisma Pertiwi'5), Idat Muqodas6), Dadan Rusdiana Saputra7)

discriminating power and difficulty level of the instrument were not tested. The development of mathematical creative thinking skills instrument in high school students is only done through face validity by experts, namely some teachers, these results indicate the instrument is feasible to be applied to eleventh-grade high school students (Fitriani \& Yarmayani, 2018). Based on the results of previous research, it shows that the development of mathematical creative thinking skills instrument that has not been seen maximally, considering that the criteria for a good instrument have medium validity, moderate reliability, good discriminating power, and the level of difficulty that is dominating, and face validity by several experts according to their fields, for example, mathematicians such as mathematics teachers in elementary schools, mathematics education lecturers, etc. Thus, in this research, the instrument development research will be carried out through a process of logical and empirical validity. Logical validity through the consideration of experts in the field of mathematics and empirical validity through the testing of the mathematical creative thinking skills instrument in the form of open questions related to problem-solving of cubes and rectangular prisms for fifth-grade students, and the instrument was tested on sixth-grade elementary school students with representative and diverse subjects.

The achievement of mathematical creative thinking skills can be measured by identifying it through open questions (Indah, Budiarto, \& Lukito, 2018; Jaenudin, Kartono, Sukestiyarno, \& Mariani, 2020). Studies suggest that mathematical creative thinking skills can be measured by tests (Suwandari \& Ibrahim, 2019). Thus, to measure the mathematical creative thinking skills of elementary school students using an open test type test instrument on the problem-solving material of volume cubes and rectangular prism.

A good instrument consists of a series of questions that gather information relevant to the research (Walton, 1997). A good test instrument is a test instrument that meets several requirements, namely valid, has high reliability, good minimum differentiation, and has a moderate level of difficulty (Puspaningtias, Yunarti, \& Yunarti, 2017). Supporting the statement, validity is defined as the extent to which the assessment accurately measures what it is intended to measure (Ramaligela, 2021). Furthermore, a reliable instrument provides a consistent characteristic measure despite fluctuations in its background (Putri, Wahyudy, Yuliyanto, \& Nuraeni, 2020). Meanwhile, the difficulty level shows the balance between easy and difficult items, and there are more easy questions between the two or show a normal curve (Lu, 2015; 
Raharjo, Ramli, \& Rinanto, 2019). The discrimination power is the assessment of the test questions to determine the skill of the test questions to discriminate students who are classified as capable and those classified as incapable (Ndiung \& Jediut, 2020). Thus, a good test instrument is an instrument that has accuracy in measuring the variables under study (validity), is consistent in measuring under certain conditions (reliability), is not too easy and not too difficult (level of difficulty), and can discriminate between high-class students, medium, and low in response to instrument (discrimination power). Development of a test instrument with several criteria to see the success of the product (Mutmainna, Mania, \& Sriyanti, 2018).

Thus, the goal of this research was to produce an instrument to measure students 'mathematical creative thinking skills on the volume of cubes and the rectangular prism of elementary school students that were accurate, consistent, had moderate difficulty, and was able to classify students' abilities well.

\section{METHODS}

The Research and Development method is applied to produce an instrument capable of measuring the mathematical creative thinking skills of fifth-grade elementary school students in problem-solving material volume cubes and rectangular prism. Research and development (R\&D) is a systematic process to develop, improve, and assess education programs and materials (Gall, Gall, \& Borg, 2010). The research design used was the development of this instrument based on the ADDIE model, which stands for Analysis, Design, Development, Implementation, and Evaluation.

In the analysis stage, the researcher examines several problems related to the mathematical creative thinking abilities of elementary school students, a measuring instrument in the form of test questions developed by the teachers whether it is appropriate to the indicators of mathematical creative thinking abilities or not. Furthermore, at the design stage, the researcher made an instrument framework in the form of a blueprint based on indicators of mathematical creative thinking skills, learning indicators, cognitive levels based on the bloom revision taxonomy and item arrangement, and the level of difficulty according to the researcher's view. At the development stage, the blueprint of the mathematical creative thinking skills instrument was submitted to a focus group discussion with experts and corrected based on the suggestions of the experts through the expert judgment sheet given by the experts. Furthermore, in the implementation stage, the researcher tested the improved 
instrument based on the advice of the expert team to the sixth-grade students to assess whether the arrangement of phrases or sentences was easy to understand, and the instrument was able to measure mathematical creative thinking skills well. The final stage in the evaluation is that the researcher reconsiders the mathematical creative thinking ability instrument based on the implementation results related to aspects that must be improved or readjusted based on the researcher's needs in measuring the mathematical creative thinking skill. Figure 1 shows a chart of research procedures carried out based on the ADDIE model.

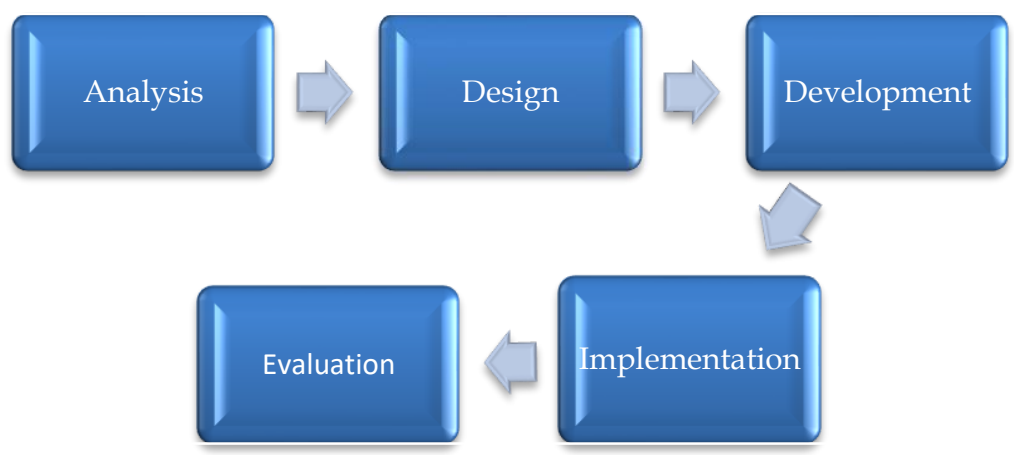

Figure 1. Research Procedure

Sixth-grade students in Jakarta and West Java were the populations of this study. The sampling technique was purposive sampling. The participants were 48 students consisting of 33 students in East Jakarta, Jakarta, and 15 students in Purwakarta, West Java. The instrument developed was an open test related to solving the volume problem of cubes and rectangular prism. Indicators that show the success of students' mathematical creative thinking abilities are determined based on four indicators, namely fluency in producing various mathematical problem-solving solutions, flexibility in producing varied mathematical problem-solving strategies, authenticity in describing the process of solving mathematical problems, and elaboration, namely the skill to describe mathematical problem-solving detail. The blueprint of the mathematical creative thinking skills instrument is presented in table 1. 
Table 1. Blueprint of Mathematical Creative Thinking Skills Instrument

\begin{tabular}{|c|c|c|c|c|}
\hline $\begin{array}{c}\text { Indicators } \\
\text { Mathematical } \\
\text { Creative Thinking } \\
\text { Skills }\end{array}$ & $\begin{array}{l}\text { Learning } \\
\text { Indicators }\end{array}$ & $\begin{array}{c}\text { Cognitive } \\
\text { Level }\end{array}$ & Questions & Item \\
\hline $\begin{array}{l}\text { 1. Fluency is the } \\
\text { capability to } \\
\text { generate more than } \\
\text { one answer to an } \\
\text { open problem } \\
\text { about the volume } \\
\text { of cubes and } \\
\text { rectangular prism } \\
\text { 2. Flexibility is the }\end{array}$ & $\begin{array}{l}4.5 \\
\text { Solving } \\
\text { problems } \\
\text { related to } \\
\text { the } \\
\text { volume of } \\
\text { a space } \\
\text { using } \\
\text { units of }\end{array}$ & Create & $\begin{array}{l}\text { Draw as many pairs } \\
\text { of rubics }(\mathrm{A}) \text { as a cube } \\
\text { and tissue holder (B) } \\
\text { in the shape of a } \\
\text { rectangular prism } \\
\text { with the same volume } \\
\text { but different surface } \\
\text { areas, and find the } \\
\text { edges! }\end{array}$ & 1 \\
\hline $\begin{array}{l}\text { capacity to apply } \\
\text { various strategies } \\
\text { to problems related } \\
\text { to the volume of } \\
\text { cubes and } \\
\text { rectangular prism } \\
\text { 3. Originality is the } \\
\text { skill to generate } \\
\text { unique and } \\
\text { unprecedented } \\
\text { answers to open } \\
\text { problems about the } \\
\text { volume of cubes } \\
\text { and rectangular } \\
\text { prism } \\
\text { 4. Elaboration, }\end{array}$ & $\begin{array}{l}\text { volume } \\
\text { (such as } \\
\text { unit } \\
\text { cubes) } \\
\text { involving } \\
\text { cubes and } \\
\text { cube roots }\end{array}$ & Analysis & $\begin{array}{l}\text { The rectangular } \\
\text { prism-shaped } \\
\text { aquarium can } \\
\text { accommodate } 5 \mathrm{dm}^{3} \\
\text { of water. If the } 2 \mathrm{~cm} \\
\text { small dice are stacked } \\
\text { from the bottom of } \\
\text { the aquarium to the } \\
\text { surface, } 10 \text { dice are } \\
\text { needed, so the height } \\
\text { of the rectangular } \\
\text { prism = the height of } \\
10 \text { piles of small } \\
\text { cubes. What length } \\
\text { and width might the } \\
\text { aquarium have? }\end{array}$ & 2 \\
\hline $\begin{array}{l}\text { namely the skill to } \\
\text { develop detailed } \\
\text { answers to open } \\
\text { problems about the } \\
\text { volume of cubes } \\
\text { and rectangular } \\
\text { prism }\end{array}$ & & Create & $\begin{array}{l}\text { Determine the names } \\
\text { and areas of objects } \\
\text { around you in the } \\
\text { form of a rectangular } \\
\text { prism with a volume } \\
\text { between } 250 \text { to } 500 \\
\mathrm{~cm}^{3} \text { ! }\end{array}$ & 3 \\
\hline
\end{tabular}

The scoring guide for mathematical creative thinking skills modifies the rubric developed by Bosch (1997) is shown in table 2. 
Aan Yuliyanto ${ }^{1)}$, Turmudi2), Ernawulan Syaodih ${ }^{3)}$, Arie Dharmawan ${ }^{4)}$, Cahya Karisma Pertiwi5), Idat Muqodas6), Dadan Rusdiana Saputra7)

Table 2. Guidelines for Scoring Mathematical Creative Thinking Skills

\begin{tabular}{|c|c|c|}
\hline Indicators & Response to Problems & Score \\
\hline \multirow{5}{*}{$\begin{array}{l}\text { Fluency is the } \\
\text { skill to } \\
\text { generate more } \\
\text { than one } \\
\text { answer to an } \\
\text { open problem } \\
\text { about the } \\
\text { volume of } \\
\text { cubes and } \\
\text { rectangular } \\
\text { prism }\end{array}$} & $\begin{array}{l}\text { Does not produce solutions that are relevant to the } \\
\text { problem }\end{array}$ & 0 \\
\hline & $\begin{array}{l}\text { Produce a solution that is relevant to the problem } \\
\text { given but is less clear in its writing }\end{array}$ & 1 \\
\hline & $\begin{array}{l}\text { Produce a solution that is relevant to the given } \\
\text { problem and is quite clear and complete in writing }\end{array}$ & 2 \\
\hline & $\begin{array}{l}\text { Produce more than one solution that is relevant to } \\
\text { the problem but is less clear in its writing }\end{array}$ & 3 \\
\hline & $\begin{array}{l}\text { Produce more than one relevant solution in solving } \\
\text { the problem and is quite clear and complete in } \\
\text { writing }\end{array}$ & 4 \\
\hline \multirow{5}{*}{$\begin{array}{l}\text { Flexibility is } \\
\text { the capacity to } \\
\text { apply various } \\
\text { strategies to } \\
\text { problems } \\
\text { related to the } \\
\text { volume of } \\
\text { cubes and } \\
\text { rectangular } \\
\text { prism }\end{array}$} & $\begin{array}{l}\text { Does not come up with a solution or come up with a } \\
\text { solution in one or more ways, but all are wrong }\end{array}$ & 0 \\
\hline & $\begin{array}{l}\text { Producing solutions in one way but there are } \\
\text { inaccuracies in the calculation process and produce } \\
\text { wrong solutions }\end{array}$ & 1 \\
\hline & $\begin{array}{l}\text { Produce solutions with one strategy with the } \\
\text { calculation process and produce the correct solution }\end{array}$ & 2 \\
\hline & $\begin{array}{l}\text { Producing solutions for more than one strategy, but } \\
\text { there are incorrect answers because there are } \\
\text { inaccuracies in the calculation process }\end{array}$ & 3 \\
\hline & $\begin{array}{l}\text { Produce solutions for more than one strategy with } \\
\text { the calculation process and produce the correct } \\
\text { solution }\end{array}$ & 4 \\
\hline \multirow{5}{*}{$\begin{array}{l}\text { Originality is } \\
\text { the skill to } \\
\text { generate } \\
\text { unique and } \\
\text { unprecedented } \\
\text { answers to } \\
\text { open problems } \\
\text { about the } \\
\text { volume of } \\
\text { cubes and } \\
\text { rectangular } \\
\text { prism }\end{array}$} & $\begin{array}{l}\text { Does not come up with solutions or come up with } \\
\text { wrong solutions }\end{array}$ & 0 \\
\hline & $\begin{array}{l}\text { Come up with a solution with their strategy but } \\
\text { difficult to understand. }\end{array}$ & 1 \\
\hline & $\begin{array}{l}\text { Produce solutions with their strategies, and the } \\
\text { calculation process is directional but not precise }\end{array}$ & 2 \\
\hline & $\begin{array}{l}\text { Producing solutions with their strategies, but there } \\
\text { are inaccuracies in the calculation process resulting } \\
\text { in wrong answers }\end{array}$ & 3 \\
\hline & $\begin{array}{l}\text { Produce solutions with their strategies through the } \\
\text { calculation process, and the results are correct. }\end{array}$ & 4 \\
\hline \multirow{2}{*}{$\begin{array}{l}\text { Elaboration, } \\
\text { namely the } \\
\text { skill to develop } \\
\text { detailed }\end{array}$} & $\begin{array}{l}\text { Does not come up with solutions or come up with } \\
\text { wrong solutions }\end{array}$ & 0 \\
\hline & $\begin{array}{l}\text { There is an inaccuracy in developing the strategy } \\
\text { without being detailed. }\end{array}$ & 1 \\
\hline
\end{tabular}




\begin{tabular}{lrlc}
\hline answers to & There is inaccuracy in developing the strategy, and & 2 \\
open problems & it is accompanied by less detailed details & \\
about the & Developing the strategy accurately and its & 3 \\
volume of & completion steps but incomplete & \\
cubes and & Developing the strategy accurately and complete & \\
rectangular & & 4 \\
prism
\end{tabular}

The development of an instrument to measure mathematical creative thinking skills is carried out with logical and empirical validity. Logical validity is through the consideration of three experts in the field of mathematics education and elementary school education, including mathematics lecturers and graduate masters of mathematics interest in the Elementary Education Program of the School of Postgraduate Studies of the Universitas Pendidikan Indonesia, as well as elementary school teachers who teach in high grades. The aspects that are evaluated in logical validity are the accuracy of the instrument items to be reviewed with the material, the accuracy of the contents used in the instrument, the sentence structure used does not offend certain individuals.

Empirical validity testing is carried out on subjects who are not examined in the research of students' mathematical creative thinking skills who are at least one level above the subject to be studied, i.e., students in sixth-grade elementary schools. The reason is that the subject has received the material to be tested on this instrumented test. Data analysis applied the help of SPSS 25, Office Excel 2019, and Anates 4.0 software (To, 1996). The decision of the validity standards is observed based on the correlation coefficient $\left(r_{x y}\right)$, and reliability is observed from the Cronbach's Alpha value. The instrument is said to be valid if the significance value $<0.05=p$ and $\mathrm{r}$ count $>\mathrm{r}$ table and has a positive value (Mahendra, 2015). While the instrument is said to be consistent in measuring or reliable if the Cronbach's Alpha value is $>0.70$, which is classified as acceptable, Cronbach's Alpha > 0.80 is classified as very good (Wells, Russell, Haraoi, Bissonnette, \& Ware, 2011). To find out the discrimination power, it can be seen with the discrimination index number (D), which shows the size of the discrimination power possessed by the item (Sukendro, Wiyatini, \& Wiradona, 2020). The difficulty level of the instrument items is known from the number (\%) of students who correctly answered the questions in the question (Wulandari, Mulyani, \& Utomo, 2013). The interpretation of the validity test used according to Guilford (1956) is shown in table 3. 
Aan Yuliyanto ${ }^{1)}$, Turmudi2), Ernawulan Syaodih ${ }^{3)}$, Arie Dharmawan ${ }^{4)}$, Cahya Karisma Pertiwi5), Idat Muqodas6), Dadan Rusdiana Saputra7)

Table 3. Interpretation of The Instrument Validity Test

\begin{tabular}{cc}
\hline Correlation Index Interval & Interpretation \\
\hline $0.800 \leq r \leq 1.000$ & Very high \\
$0.600 \leq r<0.800$ & High \\
$0.400 \leq r<0.600$ & Moderate \\
$0.200 \leq r<0.400$ & Low \\
$r<0.200$ & Very low \\
\hline
\end{tabular}

The reliability interpretation, according to Jackson (2009), is shown in table 4 .

Table 4. Interpretation of The Instrument Reliability Correlation Coefficient

\begin{tabular}{ccc}
\hline $\mathbf{r}_{11}$ Value & Correlation & Interpretation \\
\hline $0.90 \leq \mathrm{r} \leq 1.00$ & Very high & Very constant \\
$0.70 \leq \mathrm{r}<0.90$ & High & Constant \\
$0.40 \leq \mathrm{r}<0.70$ & Moderate & Sufficiently constant \\
$0.20 \leq \mathrm{r}<0.40$ & Low & Not constant \\
$\mathrm{r}<0.20$ & Very low & Very not constant \\
\hline
\end{tabular}

The interpretation of the discrimination power used according to (To, 1996) is shown in table 5.

Table 5. Interpretation of The Instrument's Discrimination Power

\begin{tabular}{cc}
\hline Classification & Interpretation \\
\hline $\mathrm{DP}<10 \%$ & Very bad, had to be thrown away \\
$10 \% \leq \mathrm{DP}<19 \%$ & Bad, better be thrown away \\
$20 \% \leq \mathrm{DP}<29 \%$ & Moderately good, need some revision \\
$30 \% \leq \mathrm{DP}<49 \%$ & Good \\
$\mathrm{DP}>50 \%$ & Very good \\
\hline
\end{tabular}

Interpretation of the difficulty level used according to Susetyo (2017) is shown in table 6.

Table 6. Interpretation of Instrument Difficulty

\begin{tabular}{cc}
\hline Classification & Interpretation \\
\hline $\mathrm{TK}<15 \%$ & Very difficult \\
$16 \% \leq \mathrm{TK}<30 \%$ & Difficult \\
$31 \% \leq \mathrm{TK}<70 \%$ & Moderate \\
$71 \% \leq \mathrm{TK}<85 \%$ & Easy \\
$86 \% \leq \mathrm{TK} \leq 100 \%$ & Very easy \\
\hline
\end{tabular}




\section{RESULTS AND DISCUSSION}

\section{Needs Analysis}

Needs analysis is carried out based on observations during the learning process and teacher and student interviews. In this study, a needs analysis related to students 'mathematical creative thinking skills found that the teachers' mathematical creative thinking skills had not yet been considered and developed properly. This is because the teacher only focuses on low-level thinking skills such as memorizing and understanding only, or in the Bloom taxonomy, it is included in $\mathrm{C} 1$ to $\mathrm{C} 3$. While the mathematical creative thinking skills is one of the higher-order thinking skills or in the bloom taxonomy, it is included in levels C4 to C6 (Anderson \& Krathwohl, 2001). Meanwhile, mathematical creative thinking skills are needed for students to solve mathematical problems in particular and generally solve problems in everyday life through information or knowledge that students have previously understood. Studies prove that mathematical creative thinking skills are skills to produce or develop something new, which is unusual, different from students' ideas by utilizing previously acquired concepts (Aziz \& Irwan, 2020). Thus, the need for a measuring instrument that can measure students' creative thinking skills well.

\section{Design}

At the design stage in this study, the researcher developed an instrument to measure the mathematical creative thinking skills of elementary school students. The researcher arranged several open-ended items based on indicators of creative thinking skills and mathematics learning indicators on the topic of solving problems of cubes and rectangular prism for fifth-grade students and based on the bloom taxonomy at levels C4 to C6. A study reveals that efforts to improve mathematical creative thinking skills can be done through problemsolving activities using open questions (Masitoh, 2015).

\section{Development}

At the development stage, the researcher develops an instrument of mathematical creative thinking skills by referring to a pre-arranged design by considering the material used, the arrangement of sentences in the questions, and is free from elements that can offend certain parties. Furthermore, the draft of the drafted instrument was submitted to several experts, including mathematics education lecturers for elementary schools, elementary school education experts, and elementary school teachers. The expert gave 
Aan Yuliyanto1), Turmudi2), Ernawulan Syaodih3), Arie Dharmawan ${ }^{4)}$, Cahya Karisma Pertiwi'5), Idat Muqodas6), Dadan Rusdiana Saputra7)

considerations related to the quality of the instrument on each item. Test readability of the questions was also carried out on the students to test whether the questions could be understood by students well. Based on experts and test legibility suggestions, these two things will be a reference for researchers to improve the instrument before it is implemented.

\section{Implementation}

At the implementation stage, the instrument is ready to be tested on sixth-grade elementary school students to understand the level of validity, reliability, difficulty level, and discriminating power on each item. The following is described in more depth.

\section{a. Test the Validity of the Mathematical Creative Thinking Skills Instrument}

The three items of the mathematical creative thinking skills instrument have passed through a logical validity process and made improvements according to expert suggestions in their fields. Furthermore, to determine the accuracy of instrument items in measuring the skill to think creatively mathematically, an empirical validity test was carried out by comparing the $r$ table with $r_{\text {count }}$ by analyzing the Pearson product-moment correlation coefficient and the significance value $\mathrm{p}$. The summary of the validity test results of the mathematical creative thinking skills is presented in table 7.

Table 7. Results of The Validity Test of The Mathematical Creative Thinking Skills Instrument

\begin{tabular}{ccccccc}
\hline Items & $\begin{array}{c}\text { Correlation } \\
\text { Value } \\
\left(\mathbf{r}_{\text {count }}\right)\end{array}$ & $\mathbf{r}_{\text {table }}$ & $\begin{array}{c}\text { Direction of } \\
\text { Correlation }\end{array}$ & $\begin{array}{c}\mathbf{p}- \\
\text { value }\end{array}$ & Criteria & Conclusion \\
\hline 1 & 0.897 & 0.285 & positive, $\mathrm{r}_{\text {count }}>\mathrm{r}_{\text {table }}$ & 0.000 & $\begin{array}{c}\text { Very } \\
\text { High }\end{array}$ & Valid \\
2 & 0.839 & 0.285 & positive, $\mathrm{r}_{\text {count }}>\mathrm{r}_{\text {table }} 0.000$ & $\begin{array}{c}\text { Very } \\
\text { High }\end{array}$ & Valid \\
3 & 0.838 & 0.285 & positive, $\mathrm{r}_{\text {count }}>\mathrm{r}_{\text {table }} 0.000$ & $\begin{array}{c}\text { Very } \\
\text { High }\end{array}$ & Valid \\
\hline
\end{tabular}

Based on table 7, all three items are considered valid. Reviewing the correlation coefficient criteria, the three items are classified as very high (Guilford, 1956; Lodico, Spaulding, \& Voegtle, 2006). This means that each item has a very strong relationship with its total score. If the item score is high, the total score will be high. Supporting these results, the instrument validity test uses the Pearson Product Moment correlation test by comparing the value of the 


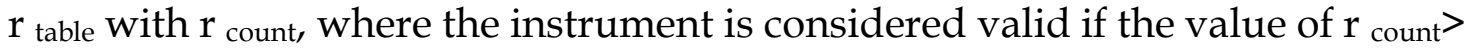
$r_{\text {table }}$ (Nursalam, 2008; Sastroasmoro \& Ismael, 2011). The validity test is carried out by considering the extent to which the question score of the developed indicators supports the total score or variables shown in the correlation coefficient with the instrument criteria considered valid if the significance is $\leq$ 0.05 (Creswell, 2009; Muhsin, Slamet, \& Wahyudin, 2017). Based on this description, the three items were assessed to be able to measure the skill to think mathematically creatively on the volume of the cube and rectangular prism material appropriately because the item score has a strong correlation with the total score. The essence of the validity test results is a benchmark that the instrument of creative thinking skills can measure correctly to describe students' mathematical creative thinking skills. The study states that a validity test is needed to determine the accuracy of the data submitted (Aliyah, 2015). Through the instrument validity test, the researcher can determine whether the instrument is feasible enough to dig up information accurately (Shahradesi, 2019; Zahra, 2015).

\section{b. Test the Reliability of the Mathematical Creative Thinking Skills Instrument}

Testing the validity of the mathematical creative thinking skills items shows that the three items have high validity criteria so that the three items can be considered to measure the mathematical creative thinking skills accurately. To determine whether the instrument can measure consistently when used repeatedly on similar subjects, the instrument reliability testing is taken at different times and places. Because the instrument is in the form of an essay test, the reliability test compares the Cronbach's Alpha value with the correlation coefficient. Cronbach's Alpha is suitable for an instrument in the form of essays (Putra, Wakhinuddin, \& Maksum, 2014; Yusup, 2018). The result of the reliability test is listed in table 8 .

Table 8. The Summary of The Reliability Test of The Mathematical Creative Thinking Skill

\begin{tabular}{cc}
\hline Cronbach's Alpha & N of Items \\
\hline 0.810 & 3 \\
\hline
\end{tabular}

Based on Cronbach's Alpha value, the instrument is classified as stable for measuring instrument in several situations such as similar subjects, different times, and places based on the correlation coefficient criteria (Jackson, 2009) in Table 4, and Cronbach's Alpha> 0.7. In line with these results, Cronbach's Alpha 
Aan Yuliyanto1), Turmudi2), Ernawulan Syaodih3), Arie Dharmawan ${ }^{4)}$, Cahya Karisma Pertiwi'5), Idat Muqodas6), Dadan Rusdiana Saputra7)

$\geq 0.7$ is considered acceptable (Xie, Li, Roos, Fong, Lo, Yeo, Yang, Chong, \& Thumboo, 2006). Instrument with a Cronbach's Alpha value $>0.7$ is considered reliable and can be used for further research (Astutik \& Priantono, 2020; Bolarinwa, 2015; Lima-Rodriguez, Lima-Serrano, \& Dominguez-Sanchez, 2015; Tsang, Royse, \& Terkawi, 2017; Wells, Russell, Haraoi, Bissonnette, \& Ware, 2011). Thus, the mathematical creative thinking skills instrument can reveal student responses that are not much different when applied to similar students even though it is implemented at different times and places. A reliability test is carried out on this instrument to prove this instrument has good consistency in measuring variables in certain situations. A reliability test is needed to determine the extent to which the results of a measurement can be trusted (Azwar, 2011). Through the reliability test, the researcher can understand how far the reliability is from the instrument itself (Aliyah, 2015; Rohandi, 2017).

\section{c. Test of The Discrimination Power Mathematical Creative Thinking Skills Instrument}

Furthermore, to determine the skill of valid instrument items to discriminate students from capable and incapable categories, a discrimination power test was conducted. The determination of the discrimination power of this test instrument is carried out with the discrimination index formula, namely by calculating the difference in the proportion of the upper class who answered correctly with the proportion of the lower class who answered correctly (Marsandi, Kusairi, \& Suwono, 2016). The results of the discrimination power test are presented in table 9.

Table 9. Recapitulation of Discrimination Power Test of Mathematical Creative Thinking Skills Instrument

\begin{tabular}{ccc}
\hline Items & Discrimination Power $\mathbf{( \% )}$ & Criteria \\
\hline 1 & 71.15 & Very good \\
2 & 53.85 & Very good \\
3 & 61.54 & Very good \\
\hline
\end{tabular}

Based on table 9 of the results of the discrimination power test, the three items have very good discrimination power criteria according to the developed discrimination power criteria (To, 1996). If each item's score for each item's discrimination power is converted to a scale of $0-1$, item 1 is 0.71 , item 2 is 0.53 , and item 3 is 0.61 . Based on the discrimination power score, all items are classified as very good. In line with these criteria, the items collected must have a discrimination power index $>0.30$ or higher (Iskandar \& Rizal, 2018; Mansyur 
\& Rasyid, 2007). The discrimination power desired is $>0.3$ because the difference will be bad if the index is $<0.3$ (Kaloka \& Sridadi, 2015). Based on this information, the three items can discriminate students classified as capable and incapable of understanding and solving problems or statements in the instrument. The results of the discrimination power test on the mathematical creative thinking skills instrument on the topic of solving the problem of cubes and rectangular prisms indicate that this instrument can discriminate students based on the upper (superior) and lower (weak) classes. In line with these assumptions, the discriminatory power test determines the difference in scores between high, medium, and low-skill students (Sakinah, Abdul, \& Lidinillah, 2018). Besides, the discriminating power test is to see whether the question is good or not to make it a product of the question (Alfajri, Maizora, \& Agustinsa, 2019).

\section{d. Test the Difficulty Level of The Mathematical Creative Thinking Skills Instrument}

The next aspect of a good instrument is that it has a moderate level of instrument difficulty. The level of difficulty is used as an indicator to determine the differences in the skills of the test takers (Jumaeda, 2016). So that the difficulty level of a good instrument must have a comprehensive variety of variations, both the questions with easy and difficult criteria should have the same number, and questions with moderate criteria have a larger portion between the two criteria. In line with this assumption, a good level of difficulty in a test is $25 \%$ difficult, $50 \%$ moderate, and 25\% easy (Widoyoko, 2014). Items with a moderate level of difficulty are considered good in measuring students' abilities. The complete level of difficulty is presented in table 10.

Table 10. The Summary of The Difficulty Level of The Mathematical Creative Thinking Skills Instrument

\begin{tabular}{ccc}
\hline Items & Level of Difficulty (\%) & Criteria \\
\hline 1 & 52.88 & Moderate \\
2 & 51.92 & Moderate \\
3 & 59.62 & Moderate \\
\hline
\end{tabular}

Based on the table above, the three items difficulty index is classified as moderate based on the difficulty level criteria developed by (Susetyo, 2017). Thus, if the three items are converted in the range $0-1$, then item 1 is 0.52 , item 2 is 0.51 , item 3 is 0.59 . Other guidelines reveal that the level of the difficulty level 
of the test items $(\mathrm{P})$ is good in the range of 0.3 to 0.7 as a description of the maximum skill of the test taker (Anderson \& Krathwohl, 2001). A good level of difficulty is a moderate level of difficulty (Purwanto, 2014). Research state that the difficulty level test is seen as the student's skills to answer the given test. The proportion of the item difficulty index ranges from 0.00 to 1.00 . The index number 0.00 can be said to be the lowest difficulty index, and 1.00 can be said to be the highest difficulty index (Lestari, Kristiantari, \& Ganing, 2018). Thus, the three items of the mathematical creative thinking skills instrument can be tested on students because they have question criteria that are not too easy or too difficult. This is because the three items have a moderate level of difficulty after being tested on students on similar subjects and various skills. The test of the level of difficulty on the creative thinking skills instrument is evidence that the items compiled are considered ideal to be applied to students. In line with the description, the difficulty level test is to find out whether the item is too difficult or too easy because a good question is neither too difficult nor too easy (Aseptianova, Nawawi, \& Yuliandina, 2019).

The results of this validity test were only limited to revealing students' mathematical creative thinking skills in solving the problem of volume cubes and rectangular prism and were only tested on sixth-grade students representing the provinces of West Java and Jakarta. Other researchers can develop further research on topics in mathematics learning and a wider subject, especially low-grade elementary school students, and develop other higherorder thinking skills.

\section{Evaluation}

In the evaluation stage, the researcher evaluates the creative thinking skills instrument based on the quality assessment by the three validators. The assessment of the quality of the instrument is based on three aspects, including the suitability of the instrument with the indicators, the suitability of the instrument with the material, and the readability of the instrument. The range of the assessment of the quality of this instrument uses a scale range of 1-5. In the following, the results of the validators assessment are presented in table 11. 
Table 11. Expert Assessment of the Quality of the Mathematical Creative Thinking skills Instrument

\begin{tabular}{clcl}
\hline No & \multicolumn{1}{c}{ Assessment Aspects } & Average & \multicolumn{1}{c}{ Criteria } \\
\hline 1 & $\begin{array}{l}\text { Suitability of the instrument } \\
\text { with the indicators }\end{array}$ & 3.4 & $\begin{array}{l}\text { Worth using/ testing with } \\
\text { revision }\end{array}$ \\
2 & $\begin{array}{l}\text { The suitability of the } \\
\text { instrument with the material }\end{array}$ & 4.6 & $\begin{array}{l}\text { Worth using/ testing } \\
\text { without revision }\end{array}$ \\
3 & Instrument readability & 2.9 & $\begin{array}{l}\text { Worth using/ testing with } \\
\text { revision }\end{array}$ \\
\hline \multicolumn{2}{c}{ Total Average } & 3.63 & $\begin{array}{l}\text { Worth using/ testing with } \\
\text { revision }\end{array}$ \\
\hline
\end{tabular}

Table 11 provides an understanding that the average value of the quality of the instrument based on the assessment of experts/validators in all aspects is 3.63 on a scale of 5.0, which is classified as Eligible to be used/tested with revisions. The research revealed that the eligibility criteria for a product were observed based on a range of 1-5, namely 1.00-2.33 the product was considered unfit for use/tested, 2.34-3.67 the product was considered Eligible to be used/tested with revisions, and 3.68-5, 00 products are deemed Eligible for use/ tested without revision (Arikunto, 2012). Reviewing the expert's assessment results, the instrument has a fairly good quality and is feasible to be tested with some improvements before it is used to measure the creative thinking abilities of fifth-grade elementary school students. Another study confirmed that before implementation, the product that had been developed was assessed for quality first by asking for an assessment from a team of experts (Wijayanti, Saputro, \& Nurhayati, 2015).

\section{CONCLUSION}

The mathematical creative thinking skills instrument developed for sixth-grade and can be used for fifth-grade elementary school students in mathematics learning related to the problem-solving material of the volume of cubes and rectangular prisms as many as 3 items can be used as a good measuring tool to measure similar subjects, although in different situations because it is based on assessment instrument experts are considered good and feasible to use and based on the results of the trial, the instrument is classified as accurate, consistent, has a good level of difficulty and can discriminate students' abilities. 
Aan Yuliyanto1), Turmudi2), Ernawulan Syaodih3), Arie Dharmawan ${ }^{4)}$, Cahya Karisma Pertiwi'5), Idat Muqodas6),

\section{REFERENCES}

Al-Mahasneh, R. (2018). The role of teachers in establishing an attractive environment to develop the creative thinking among basic stage students in the schools of tafilah governorate according to their own perspective. Journal of Curriculum and Teaching, 7(1), 206. https:// doi.org/10.5430/jct. v7n1p206.

Alfajri, A. R., Maizora, S., \& Agustinsa, R. (2019). Kepraktisan soal-soal higher order thinking untuk menghasilkan soal yang praktis untuk siswa kelas XI MAN 1 Kota Bengkulu. Jurnal Penelitian Pembelajaran Matematika Sekolah (JP2MS), 3(2), 188-195. https:// doi.org/10.33369/jp2ms.3.2.205-217.

Aliyah, S. (2015). Hubungan bermain balok dengan perkembangan kognitif anak usia 4-5 tahun di RA Miftahul Ulum tahun 2013-2014. SELING: Jurnal Program Studi PGRA, 1(1), 31-45. https:/ / doi.org/10.29062/seling. v1i1.235.

Anderson, L. W., \& Krathwohl, D. R. (2001). A taxonomy for learning, teaching, and assessing: a revision of bloom's taxonomy of educational objectives. New York: Addison Wesley Longman, Inc.

Arifuddin, A. (2019). Students' critical and creative thinking skills on mathematics learning in madrasah ibtidaiyah. AULADUNA: Jurnal Pendidikan Dasar Islam, 6(1), 38. https://doi.org/10.24252/auladuna. v6i1a5.2019.

Arikunto, S. (2012). Dasar-dasar evaluasi pendidikan. Jakarta: Bumi Aksara.

Ariyana, Y., Pudjiastuti, A., Bestary, R., \& Zamromi. (2018). Buku Pegangan Pembelajaran Keterampilan Berpikir Tingkat Tinggi Berbasis Zonasi. Jakarta: Direktorat Jendral Guru dan Tenaga Kependidikan.

Aseptianova, A., Nawawi, S., \& Yuliandina, M. (2019). Pengembangan asesmen biologi berbasis keterampilan berpikir kritis siswa kelas XI semester genap di SMA Muhammadiyah 1 Palembang. Bioedukasi (Jurnal Pendidikan Biologi), 10(1), 1-13. https://doi.org/10.24127/bioedukasi. v10i1.2001.

Astuti, A., Waluya, S. B., \& Asikin, M. B. (2020). Instrumen kemampuan berpikir kreatif matematika untuk siswa kelas IV Sekolah Dasar. Musamus Journal of Primary Education, 3(1), 27-34. https:/ / doi.org/10.35724/musjpe.v3i1. 3117.

Astutik, M., \& Priantono, S. (2020). Pengaruh karakteristik pekerjaan terhadap kinerja karyawan dan kepuasan kerja dengan variabel moderator budaya kerja pada badan keswadayaan masyarakat (BKM) di Kota Probolinggo. Jurnal Manajemen, 17(1), 81-97. https:/ / doi.org/10.25170/jm.v17i1.1296.

Aziz, S. A., \& Irwan, I. (2020). Validity of mathematical learning material based on model eliciting activities (MEAS) approach to improve mathematical creative thinking skill of students. Journal of Physics: Conference Series, 1554(1), 012066. https:// doi.org/10.1088/1742-6596/1554/1/012066. 
Azwar, S. (2011). Reliabilitas dan validitas. Yogyakarta: Pustaka Pelajar.

Bolarinwa, O. A. (2015). Principles and methods of validity and reliability testing of questionnaires used in social and health science researches. Niger Postgrad Med, (22), 195-201. https://doi.org/10.4103/1117-1936. 173959.

Bosch, N. (1997). Rubric for creative thinking skills evaluation. Retrieved from https:/ / adifferentplace.org/creativethinking.html.

Creswell, J. W. (2009). Research design: Qualitative, quantitative, and mixed methods approaches (Third). California: Sage Publication, Inc.

Evans, J. R. (1994). Creative thinking in the decision and management sciences. Cincinnati: South-Western Publishing Co.

Firdaus, As'ari, A. R., \& Qohar, A. (2018). Meningkatkan kemampuan berpikir kreatif matematis siswa SMA melalui pembelajaran open-ended pada materi SPLDV. Jurnal Pendidikan: Teori, Penelitian, dan Pengembangan, 1(2), 227-236. https:/ / doi.org/10.20956/jmsk.v15i2.5719.

Fitriani, S., \& Yarmayani, A. (2018). Pengembangan rubrik berpikir kreatif siswa menengah atas dalam menyelesaikan masalah matematika. Mosharafa: Jurnal Pendidikan Matematika, 7(1), 33-38. https://doi.org/10.31980/ mosharafa.v7i1.339.

Fitriyah, L. (2020). Pengaruh PISA (Program for International Student Assessment) terhadap pendidikan di Indonesia. Academia Edu.

Gall, M. D., Gall, J. P., \& Borg, W. R. (2010). Applying educational research. New York: Pearson Education, Inc.

Guilford, J. P. (1956). Fundamental statistics in psychology and education. New York: McGraw-Hill.

Indah, N., Budiarto, M. T., \& Lukito, A. (2018). The open-ended problem based mathematics learning to increase students creativity on fraction for third grade elementary school. Proceedings of the Mathematics, Informatics, Science, and Education International Conference (MISEIC 2018), 157(Miseic), 77-80. https:// doi.org/10.2991/miseic-18.2018.19.

Ishabu, L. S., Budayasa, I. K., \& Siswono, T. Y. E. (2019). Creative thinking process of female elementary school student with visual learning style in mathematical problem-solving. Journal of Physics: Conference Series, 1265(1). https://doi.org/10.1088/1742-6596/1265/1/012018.

Iskandar, A., \& Rizal, M. (2018). Analisis kualitas soal di perguruan tinggi berbasis aplikasi TAP. Jurnal Penelitian dan Evaluasi Pendidikan, 22(1), 1223. https://doi.org/10.21831/pep.v22i1.15609.

Jackson, S. L. (2009). Research methods and statistics a critical thinking approach (Third). Retrieved from https://ichapters.com.

Jaenudin, A., Kartono, Sukestiyarno, Y. L., \& Mariani, S. (2020). The identification of students' mathematical creative thinking ability on transformation geometry. Proceedings of the International Conference on 
Aan Yuliyanto1), Turmudi2), Ernawulan Syaodih3), Arie Dharmawan ${ }^{4)}$, Cahya Karisma Pertiwi'5), Idat Muqodas6),

Dadan Rusdiana Saputra7)

Science and Education and Technology (ISET 2019), 443, 101-104. https:// doi.org/10.2991/assehr.k.200620.020.

Jumaeda, S. (2016). Komparasi bentuk tes pilihan ganda dengan tes menjodohkan (matching test) ditinjau dari tingkat kesukaran pada mata pelajaran bahasa arab di MAN Waimital Kabupaten Seram bagian Barat. Al-Iltizam: Jurnal Pendidikan Agama Islam, 1(1), 55-71. http:/ / dx.doi.org/ 10. 33477/alt.v1i1.186.

Kaloka, P. T., \& Sridadi. (2015). Evaluasi butir soal ulangan akhir semester gasal kesehatan pada kelas khusus bakat istimewa olahraga (BIO) di SMA Negeri 4 Yogyakarta. Jurnal Pendidikan Jasmani Indonesia, 11(2), 101-110. https:/ / doi.org/10.21831/jpji.v11i2.8186.

Kemendikbud. (2003). Undang-undang No 20 Tahun 2003 tentang sistem pendidikan nasional. Jakarta: Kementerian Pendidikan dan Kebudayaan.

Kusumastuti, I., Fauziati, E., \& Marmanto, S. (2019). Challenged for higherorder thinking skill implementation: reports from efl classroom teachers. International Journal of Language Teaching and Education, 3(2), 108-117. https: //doi.org/10.22437/ijolte.v3i2.7579.

Lestari, N. K. T., Kristiantari, M. R., \& Ganing, N. N. (2018). Pengaruh model pembelajaran talking stick berbantuan lagu daerah terhadap hasil belajar IPS. International Journal of Elementary Education, 1(4), 290-297. https:// doi. org/10.23887/ijee.v1i4.12960.

Lima-Rodriguez, J. S., Lima-Serrano, M., \& Dominguez-Sanchez, I. (2015). Psychometric properties of an instrument to measure family disease management. International Journal of Clinical and Health Psychology, 15(3), 253-264. https://doi.org/10.1016/j.ijchp.2015.05.002.

Lodico, M. G., Spaulding, D. T., \& Voegtle, K. H. (2006). Methods in Educational Research from Theory to Practice. https:/ / doi.org/10.1177/0013124575007 00301.

Lu, Y. (2015). 10 Working memory, cognitive resources, and L2 writing performance. In Working Memory in Second Language Acquisition and Processing, 87. Bristol: Multilingual Matters.

Mahendra, I. (2015). Analisa penerimaan pengguna sistem informasi koperasi pada koperasi karyawan budi setia Jakarta dengan technology acceptance model. Jurnal Pilar Nusa Mandiri, 11(1), 70-80. Retrieved from http:/ / ejournal.nusamandiri.ac.id/index.php/pilar/article/view/415.

Mansyur, \& Rasyid, H. (2007). Penilaian Hasil Helajar. Bandung: Wacana.

Marsandi, Kusairi, S., \& Suwono, H. (2016). The development of formative assessment on the material of the senses of vision and optical devices. Prosiding Seminar Nasional II, 2, 410-422. Retrieved from http:/ / researchreport.umm.ac.id/index.php/research-report/article/view/616.

Masitoh, L. F. (2015). Meningkatkan dan mengukur kemampuan berpikir kreatif matematis. Seminar Nasional Matematika dan Pendidikan Matematika

80| Volume 9, No 1, June 2021 
UNY. pp. 365-370. Yogyakarta: Universitas Negeri Yogyakarta.

McGuinness, C. (1999). From thinking skills to thinking classrooms: A review and evaluation of approaches for developing pupils' thinking. London: Department for Education and Employment London.

Moma, L. (2016). Pengembangan Instrumen kemampuan berpikir kreatif matematis untuk siswa SMP. Delta-Pi: Jurnal Matematika dan Pendidikan Matematika, 4(1), 27-41. http:/ /dx.doi.org/10.33387/dpi.v4i1.142.

Muhsin, Slamet, A., \& Wahyudin, A. (2017). Educational mixed marketing strategies and sustainable competitive advantages in mediating the influence of marketing orientation over marketing. The Journal of Educational Development, 5(2), 153-171. Retrieved from https://journal. unnes.ac.id/sju/index.php/jed/article/view/14299.

Mutmainna, D., Mania, S., \& Sriyanti, A. (2018). Pengembangan instrumen tes diagnostik pilihan ganda dua tingkat untuk mengidentifikasi pemahaman konsep matematika. MaPan, 6(1), 56-69. https://doi.org/ 10.24252/mapan. 2018v6n1a6.

National Council of Teachers of Mathematics. (2000). Principles standards for school mathematics. Retrieved from https://nctm.org.

National Research Council. (2001). Adding it up (J. Kilpatrick, J. Swafford, \& B. Findell, Eds.).

Ndiung, S., \& Jediut, M. (2020). Pengembangan instrumen tes hasil belajar matematika peserta didik sekolah dasar berorientasi pada berpikir tingkat tinggi. Premiere Educandum: Jurnal Pendidikan Dasar Dan Pembelajaran, 10(1), 94. https:/ / doi.org/10.25273/pe.v10i1.6274.

Nursalam. (2008). Konsep dan Penerapan Metodologi Penelitian Ilmu Keperawatan. Jakarta: Salemba Medika.

Oktiningrum, W., \& Wardhani, D. A. P. (2019). Kemampuan pemecahan masalah matematis siswa sekolah dasar melalui soal higher order thinking skills. MaPan : Jurnal Matematika dan Pembelajaran, 7(2), 281-290. https:// doi.org/10.24252/mapan.2019v7n2a8.

Pitrianti, S. (2017). The implementation of problem-based learning in writing discussion text on indonesian language learning. IJAEDU- International E-Journal of Advances in Education, 3(9), 620-627. https://doi.org/10. 18768/ijaedu.370432.

Putra, A. F., Wakhinuddin, \& Maksum, H. (2014). Hubungan motivasi belajar dengan hasil belajar praktek siswa kelas $X$ program keahlian teknik kendaraan ringan pada mata pelajaran teknik las otomotif dasar di SMK Negeri 5 Padang. Automotive Engineering Education Journals, 2(1). Retrieved from http://ejournal.unp.ac.id/students/index.php/poto/ article/view/3152.

Purwanto. (2014). Evaluasi hasil belajar. Yogyakarta: Pustaka Pelajar. 
Aan Yuliyanto1), Turmudi2), Ernawulan Syaodih3), Arie Dharmawan ${ }^{4)}$, Cahya Karisma Pertiwi'5), Idat Muqodas6),

Puspaningtias, A. A., Yunarti, S., \& Yunarti, T. (2017). Efektivitas model discovery learning ditinjau dari pemahaman konsep matematis siswa. Jurnal Pendidikan Matematika Unila, 5(9), 1003-1014. Retrieved from http://jurnal.fkip.unila.ac.id/index.php/MTK/article/view/14204.

Putri, H. E., Wahyudy, M. A., Yuliyanto, A., \& Nuraeni, F. (2020). Development of instruments to measure mathematical anxiety of elementary school students. International Journal of Learning, Teaching and Educational Research, 19(6), 282-302. https:/ / doi.org/10.26803/ijlter.19.6.17.

Raharjo, D., Ramli, M., \& Rinanto, Y. (2019). Diagnostic test assessment on protist misconception. Jurnal Pendidikan Biologi Indonesia, 5(2), 335-344. https:// doi.org/10.22219/jpbi.v5i2.7685.

Rahayu, \& Ulya, H. (2017). Practicality of ethnomathematics learning instruments on fraction materials for elementary school students. International Conference on Mathematics, Science, and Education, 90-95. Retrieved from https://journal.unnes.ac.id/sju/index.php/icmse/ article/view/23715.

Ramaligela, S. M. (2021). Student's Perceptions of assessment legitimacy in TVET Sector in South Africa. In M. Makgato \& G. Afeti (Eds.), New Models for Technical and Vocational Education and Training. 162-181. https:// doi.org/10.4018/978-1-7998-2607-1.ch009.

Rambe, J., Sinaga, B., \& Yusnadi. (2018). The development of learning devices based on discovery learning to improve mathematical creative thinking ability of students class V at SD Negeri 060827 Medan Amplas. Journal of Education and Practice, 9(9), 72-79. Retrieved from https:/ / www.iiste.org /Journals/index.php/JEP/article/view/41739.

Rizki, M. (2018). Implementasi model pembelajaran pemaknaan dalam meningkatkan keterampilan berpikir kreatif mahasiswa PGMI STIT Muhammadiyah Bojonegoro. INVENTA, 2(2), 83-90. https://doi.org/10. 36456/inventa.2.2.a1653.

Rohandi, M. M. A. (2017). Effectiveness C2C e-commerce media in bandung (case study at tokopedia.com and bukalapak.com). Jurnal Manajemen dan Bisnis: Performa, 14(2), 177-197. https://doi.org/10.29313/performa. v0i2.3628.

Rosana, K., \& Ekohariadi. (2020). Penggunaan web-based learning di sekolah menengah menggunakan strategi berpikir kreatif. Jurnal IT-EDU, 5(1), 113-120. Retrieved from https://ejournal.unesa.ac.id/index.php/itedu/article/view/36461.

Rosyanti, A., Rohaendi, A., \& Zanthy, Sylviana, L. (2019). Analisis kemampuan berpikir kreatif dan pemecahan masalah matematik serta kepercayaan diri siswa SMP menggunakan pendekatan kontekstual. Journal on Education, 1(3), 182-190. Retrieved from http:/ / www.jonedu.org/index. php/joe/article/view/136. 
Sakinah, E., Abdul, D., \& Lidinillah, M. (2018). Penggunaan model Means Ends Analysis (MEA) untuk meningkatkan kemampuan berpikir kritis matematis siswa pada materi penjumlahan dan pengurangan pecahan. PEDADIDAKTIKA: Jurnal Ilmiah Pendidikan Guru Sekolah Dasar, 5(4), 149156. Retrieved from https:/ / ejournal.upi.edu/index.php/pedadidaktika /article/view/12884.

Sastroasmoro, S., \& Ismael, S. (2011). The basics of clinical research methodology. Jakarta: Sagung Seto.

Sener, N., Turk, C., \& Tas, E. (2015). Improving science attitude and creative thinking through science education project: a design, implementation, and assessment. Journal of Education and Training Studies, 3(4), 57-67. https://doi.org/10.11114/jets.v3i4.771.

Setiawan, A., Malik, A., Suhandi, A., \& Permanasari, A. (2018). Patent no. 000103371.

Shahradesi, Y. (2019). Hubungan kepemimpinan, motivasi dan kompensasi terhadap kepuasan kerja perawat rawat inap RSUD Sidikalang Kabupaten Dairi tahun 2018. Jurnal Ilmiah Kohesi, 3(2), 11-17.

Silvia, F., Risnita, R., \& Syaiful, S. (2015). Pengembangan rubrik keterampilan berpikir kreatif dalam memecahkan masalah matematika siswa kelas VIII SMP Attaufiq Jambi. Edu-Sains: Jurnal Pendidikan Matematika Dan Ilmu Pengetahuan Alam, 4(1), 10-21. https://doi.org/10.22437/jmpmipa. v4i1.2363.

Sukendro, S. J., Wiyatini, T., \& Wiradona, I. (2020). Evaluation of online learning during the covid-19 pandemic through the application of computerbased examination (CBT) by lecturers of the department of dental nursing, ministry of health, semarang academic year 2020/2021. Jurnal Kesehatan Gigi, 7(2), 133-140. https:/ / doi.org/10.31983/jkg.v7i2.6546.

Susetyo, B. (2017). Statistika untuk analisis data penelitian. Bandung: Refika Aditama.

Suwandari, S., \& Ibrahim, M. (2019). Application of discovery learning to train the creative thinking skills of elementary school students. International Journal of Innovative Science and Research Technology, 4(12), 410-417.

To, K. (1996). Mengenal analisis tes. Bandung: Jurusan Psikologi Pendidikan dan Bimbingan FIP IKIP Bandung.

Tohir, M. (2019). Hasil PISA Indonesia tahun 2018 turun dibanding tahun 2015. 12. https:// doi.org/10.31219/osf.io/pcjvx.

Tsang, S., Royse, C. F., \& Terkawi, A. S. (2017). Guidelines for developing, translating, and validating a questionnaire in perioperative and pain medicine. Saudi Journal of Anaesthesia, 11(1), S80-S89. https://doi.org/ 10.4103/sja.SJA_203_17.

Walton, L. W. (1997). Telephone survey: answering the seven Rs to logistics research. Journal of Business Logistics, 18(1). 
Aan Yuliyanto1), Turmudi2), Ernawulan Syaodih3), Arie Dharmawan ${ }^{4)}$, Cahya Karisma Pertiwi'5), Idat Muqodas6),

Wang, C., Wu, J., \& Horng, R. (1999). Creative Thinking ability, cognitive type, and R\&D performance. RED Management, 29(3), 247-254. https://doi. org/10.1111/1467-9310.00134.

Wells, G. A., Russell, A. S., Haraoi, B., Bissonnette, R., \& Ware, C. F. (2011). Validity of quality of life measurement tools - from generic to diseasespecific. The Journal of Rheumatology, 88, 2-6. https://doi.org/10.3899/ jrheum.110906.

Widoyoko, S. E. P. (2014). Penilaian hasil pembelajaran di sekolah. Yogyakarta: Pustaka Belajar.

Wijayanti, D., Saputro, S., \& Nurhayati, N. (2015). Pengembangan media lembar kerja siswa (LKS) berbasis hierarki konsep untuk pembelajaran kimia kelas $\mathrm{X}$ pokok bahasan pereaksi pembatas. Jurnal Pendidikan Kimia Universitas Sebelas Maret, 4(2), 15-22. Retrieved from https://jurnal.fkip. uns.ac.id/index.php/kimia/article/view/5645.

Wulandari, D., Mulyani, S., \& Utomo, S. B. (2013). Pembelajaran kimia berwawasan CET (chemoedutainment) dengan eksperimen menggunakan laboratorium virtuil dan riil ditinjau dari gaya belajar terhadap prestasi belajar siswa. Jurnal Pendidikan Kimia, 2(1), 29-35. Retrieved from https://jurnal.fkip.uns.ac.id/index.php/kimia/article/ view/492.

Xie, F., Li, S. C., Roos, E. M., Fong, K. Y., Lo, N. N., Yeo, S. J., Yang, K. Y., Chong, H. C., \& Thumboo, J. (2006). Cross-cultural adaptation and validation of Singapore English and Chinese versions of the knee injury and osteoarthritis outcome score (KOOS) in asians with knee osteoarthritis in Singapore. Osteoarthritis and Cartilage, 14(11), 1098-1103. https:/ / doi.org /10.1016/j.joca.2006.05.005.

Yani, A. T., \& Oikawa, S. (2019). Increasing creative and innovative thinking ability through the strengthening of character education in probability theory course. JETL (Journal Of Education, Teaching and Learning), 4(1), 163. https:/ / doi.org/10.26737/jetl.v4i1.990.

Yusup, F. (2018). Uji validitas dan reliabilitas instrumen penelitian kuantitatif. Jurnal Tarbiyah: Jurnal Ilmiah Kependidikan, 7(1), 17-23. https:// doi.org/ 10.18592/tarbiyah.v7i1.2100.

Zahra, N. (2015). Pengaruh gaya kepemimpinan terhadap komitmen organisasi melalui aspek kepuasan kerja karyawan dan kepercayaan pada sektor perbankan. Jurnal Manajemen dan Pemasaran Jasa, 8(1), 145-162. https:// doi.org/10.25105/jmpj.v8i1.1406. 